\title{
A Reconsideration of the Leilou - Longbian Debate: A Continuation of Research by Nishimura Masanari
}

\author{
Phạm Lê Huy \\ Vietnam National University-Hanoi \\ hrg95vn@gmail.com
}

\begin{abstract}
In 111 BCE, the Han Dynasty destroyed the Nanyue Kingdom and put the region under the Jiaozhi Commandery. The headquarters of the Jiaozhi Commandery was originally Miling, but was later moved to Leilou and then to Longbian. There have been many hypotheses regarding the location of Leilou and Longbian. In particular, many scholars have identified the remains of the old citadel (Lũng Khê Citadel) located in Thuận Thành District (Bắc Ninh, Vietnam) with the Leilou Citadel. Based on archaeological evidence, the late Dr. Nishimura Masanari advanced a new hypothesis that these remains were not the citadel of Leilou, but that of Longbian. This article will review historical documents about Leilou and Longbian and introduce two inscriptions recently discovered in Bắc Ninh Province to provide further support for Nishimura's hypothesis.
\end{abstract}

\section{Keywords}

Jiaozhi Commandery - Leilou - Longbian - Lũng Khê citadel - Nishimura Masanari

\section{Literature Review}

In 111 BCE, the Han Dynasty (206 BCE-220 CE) destroyed the Kingdom of Nanyue and annexed its territory. Inheriting the administrative system of Nanyue, the Han put the region of Nanyue under the Jiaozhi Commandery (交趾郡). The headquarters of the Jiaozhi Commandery was originally Miling (麇泠, Vietnamese: Mê Linh), but was later moved to Leilou (贏㜢, Vietnamese: Luy Lâu) and then to Longbian (龍編, Vietnamese: Long Biên). So far, there 
have been several hypotheses concerning the location of the Leilou and Longbian citadels.

The first hypothesis (hereafter Hypothesis 1), proposed by Henri Maspero, holds that the Leilou Citadel was located south of Hanoi. Maspero cited a note in Yuanhe junxian tuzhi (元和郡縣圖志) that suggested that Leilou was located 75 li (里) northwest of the Tang's Protectorate Citadel. ${ }^{1}$ This hypothesis, however, has been criticized for its lack of evidence, as it relies on a single piece of evidence. $^{2}$

The second hypothesis (hereafter Hypothesis 2, simplified as "Lũng Khê = Leilou”), proposed by Claude Madrolle based on fieldwork by Henry Wintrebert, holds that the Leilou Citadel was located at the same place as the later Lung Khê Citadel (Thuận Thành, Bắc Ninh). ${ }^{3}$ This hypothesis has been backed and developed by many other scholars, ${ }^{4}$ based on the following sources. First, Việt sủ thông giám cương muc (越史通鑑綱目) and Đại Nam nhất thống chí (大南 一統志), compiled under the Nguyễn (1802-1945), both affirm that the Lũng Khê Citadel was the Leilou Citadel under Han rule. Second, Việt điện u linh (粵甸幽靈), compiled under the Trần (1225-1400), suggests that Shi Xie (士燚, Vietnamese: Sĩ Tiếp/Nhiếp, 137-226), the head of Jiaozhi Commandery, based his headquarters in Leilou. Ngụy Việt ngoại kỷ (偽越外紀), cited in Annan zhi (安南志), which was compiled under the Ming (1368-1644), also states that Shi Xie built the Leilou Citadel. In fact, the inner and surrounding areas of the Lũng Khê Citadel include many relics and legends related to Shi Xie. Also, as Sakurai Yumio observed, the view that Leilou was located at Lũng Khê does not contradict the notes on rivers in Shuijing zhu (水經注). ${ }^{5}$

Based on Hypothesis 2, scholars such as Đỗ Văn Ninh argue that the Leilou Citadel was also the Longbian Citadel under the Han, and that both were the same as the Lũng Khê Citadel (hereafter Hypothesis 3, simplified as "Lũng

1 Henri Maspero, "Etudes d'histoire d'Annam," BEFEO 18 (1918): 11-12.

2 Sakurai Yumio 桜井由躬雄, “A Reconsideration of Lạc điền-A Discussion of the Reclamation of the Red River Delta in the Ancient Period" ( $く$ 田問題の整理 : 古代紅河 デルタ開拓試論), Journal of Southeast Asia Studies (東南アジア研究) 17, no. 1 (1979): 19.

3 Claude Madrolle, "Le Tonkin ancien. Lei-leou 贏 (音連) 㜢 et les districts chinois de l'époque des Han. La population. Yue-chang," BEFEO 37 (1937): 267-271.

4 Trần Quốc Vượng, "A Geographical-Historical Issue: Political Centres of our Country in the Ancient Era (From the late Primitive Communism to the Han Rule)," (Một vấn đề địa lí học lịch sử: Những trung tâm chính trị của đất nước ta trong thời cổ đại), Journal of Historical Studies (Nghiên cứu Lịch sử) 6 (1959): 36-37; Đào Duy Anh, Vietnam through Ages: A Historical and Geographical Study of Vietnam (Đất nước Việt Nam qua các đời) (Hanoi: Science Publisher (NXв Khoa học), 1964), 51; Sakurai, "A Reconsideration of Lạc điền," 18-19.

5 Sakurai, “A Reconsideration of Lạc điền," 19. 
Khê = Leilou = Longbian"). The equation of Leilou with Longbian is based on records in Đại Việt sủ ký toàn thu' (Toàn thu') (大越史記全書). ${ }^{6}$ However, this hypothesis was criticized by Trần Quốc Vượng because in many historical documents from the Han to the Song period (960-1279), Leilou and Longbian are described as two different administrative units. ${ }^{7}$

In 2011, based on his excavation at Lũng Khê, Nishimura Masanari proposed a new theory, arguing that the Lũng Khê Citadel is the Longbian Citadel, and both are distinct from the Leilou citadel (hereafter Hypothesis 4, simplified as "Lũng Khê = Longbian $\neq$ Leilou"). Nishimura's hypothesis is based on three lines of reasoning. First, although he did not pursue an in-depth analysis, Nishimura did question the reliability of historical documents (the earliest being Việt diện $u$ linh) that hold that Lũng Khê was Leilou. Second, in reference to Jiaozhou department heads such as Bu Zhi (步篤), Nishimura recognized that these mandarins' titles often included the names of the places where they established their headquarters. As Shi Xie received the title of "Longbian marquess" (龍編侯), Nishimura believed that Shi Xie's headquarters was at Longbian. Therefore, the Lũng Khê Citadel, with many relics and legends associated with Shi Xie, should be at Longbian, not Leilou. Third, results from archaeological excavations by Nishimura and Vietnamese archaeologists have also suggested that the Lũng Khê Citadel was occupied in the period between the Late Han $(25 \mathrm{CE}-220 \mathrm{CE})$ and the Sui period (581-618), which coincided with the period when the Longbian Citadel was occupied according to historical records. ${ }^{8}$

A review of the literature on the Leilou-Longbian-Lũng Khê question highlights several shortcomings. First, when discussing the issue of Leilou and Longbian, it is crucial to note that Leilou and Longbian were the headquarters of the Jiaozhi Commandery. As will be discussed in the second section of this paper, under Han rule there were two parallel administrative units in the region: the Jiaozhi Commandery and the Jiaozhi Department, headed respectively by the Jiaozhi taishou (交趾太守) and the Jiaozhi cishi (交趾刺史). Differentiating between the two headquarters of these two administrative units, the author will analyze their relationship, changes in their location over time, and the relationship between Leilou, Longbian, and Shi Xie.

Second, although many works mention Leilou and Longbian, no study has offered a comprehensive and systematic analysis of the relevant historical

6 Đỗ Văn Ninh, Ancient Towns in Vietnam (Đô thị cổ Việt Nam) (Hanoi: Institute of History, 1989), 82-84.

7 Trần Quốc Vượng, "The Position of Luy Lâu” (Vị thế Luy Lâu), Journal of Historical Studies (Nghiên cứu Lịch sử) 315 (2001): 3-7.

8 Nishimura Masanari, Archaeology and Ancient History of Vietnam (Betonamu no KokoKodaigaku) (Tokyo: Doseisha, 2011), 155-176. 
records. Information about Leilou and Longbian is distributed across a tremendous amount of material dated between the early Common Era and the early twentieth century. Within this vast historical time span, it seems that at certain points, in addition to the original data, some misinformation about Leilou-Longbian emerged and was later taken to be reliable. The subsequent use and interpretation of the original data and the later misleading information has yielded sedimentary layers of material in conflict with each other. It is difficult to locate Leilou and Longbian without properly distinguishing these layers. Indeed, it was the accumulation of undifferentiated historical and nonhistorical data that gave rise to the diverse hypotheses on Leilou, Longbian, and Lũng Khê.

In this context, Nishimura Masanari proposed some important steps toward solving the problem by combining archaeological evidence with written records. Based on the existing scholarly literature and particularly the ideas advanced by Nishimura, the author will try to separate the accumulated data into the sedimentary layers that led to each hypothesis. The author thereby attempts to recover the original sources in order to shed further light on the issue of Leilou and Longbian.

\section{The Headquarters of the Jiaozhi Commandery and the Jiaozhi Department}

To clarify the relationship between Leilou and Longbian, it is important to distinguish between two administrative units, the Jiaozhi Commandery and the Jiaozhi Department, and their respective headquarters.

The name Jiaozhi originated from the name of one of the two commanderies established on the territory of Âu Lac (甌雒) by the Nanyue Kingdom, namely, Jiaozhi (交趾) and Jiuzhen (九真). The Nanyue administrated the two commanderies via two representatives, known as the "two envoys" (二使者). After the conquest of the Nanyue in 111 BCE, the Han Dynasty maintained the system of two commanderies, Jiaozhi and Jiuzhen, designating the heads of both commanderies as taishou (太守).

In parallel with the Jiaozhi Commandery, the Han established a new administrative unit with the same name, the Jiaozhi Department. ${ }^{9}$ Five years after the conquest of the Nanyue, in 106 всE, the Han divided the whole country into thirteen "departments" (刺史部), each headed by a cishi (刺史). The Jiaozhi Department included seven commanderies: Nanhai (南海), Cangwu

9 The Jiaozhi Department is mentioned in the chapter Zhu Jun 朱售 in Houhan Shu. 「會交 阯部莙賊並起, 牧守輀弱不能禁」(『後漢書』卷 71 , 朱儶傳). 
(荅梧), Hepu (合浦), Yulin (鬱林), Jiaozhi (交趾), Jiuzhen (九真), and Rinan (日南). ${ }^{10}$ It is noteworthy that out of the thirteen departments, apart from Jiaozhi and Shuofang (朔方), the other eleven departments had the suffix-zhou, such as the Qingzhou (青州) Department or the Xuzhou (徐州) Department. Therefore, the Jiaozhi Department was equal to a zhou, and the headquarters of the Jiaozhi Department was regarded as the center of a zhou (州治). In 203 $\mathrm{CE}$, for the sake of consistency, the Jiaozhi Department was renamed Jiaozhou (交州) (also known as the Jiaozhou Department).

Thus, under Han rule, in the period between 106 BCE and 203 CE, there were two administrative units with the name Jiaozhi: the Jiaozhi Commandery (交趾郡) and the Jiaozhi Department (交趾 [刺史]部). The Jiaozhi Department was the higher-level unit, supervising the Jiaozhi Commandery. The head of the department was the Jiaozhi cishi, and the head of the commandery was the Jiaozhi taishou. In $203 \mathrm{CE}$, Emperor Xian of the Han, on the advice of the Jiaozhi cishi, Zhang Jin (張津), and the Jiaozhi taishou, Shi Xie, decided to rename the Jiaozhi Department the Jiaozhou (Department). ${ }^{11}$ This crucial issue has not received sufficient attention, and confusion has arisen over the headquarters of these two administrative units.

As highlighted above, the headquarters of the Jiaozhi Commandery was the commandery center (郡治 or 郡守) of the Jiaozhi taishou. The headquarters of the Jiaozhi Department, meanwhile, was the department center (州治) of the Jiaozhi cishi (and later the Jiaozhou cishi). As the Jiaozhi cishi ruled over all seven commanderies, the department center could have been located anywhere within the boundaries of the seven commanderies. The headquarters of the Jiaozhi taishou, however, had to be somewhere within the boundaries of the Jiaozhi Commandery. The following paragraphs trace the shifting location of the headquarters of the Jiaozhi Commandery and the Jiaozhi Department.

According to Jiaozhou waiyuji (交州外域記), cited in Shuijing zhu, initially the headquarters of both the Jiaozhi Commandery and the "original" headquarters of the Jiaozhi Department (州本治) were located in Miling County. ${ }^{12}$ Wang Fan's (王範) Jiaoguang chunqiu (交廣春秋), written under

$10 \quad$ Shuijing zhu states that the appointment of the Jiaozhi Department head was made in 116 BCE (元鼎 2), which might be a mistake because at that time the Nanyue was still in power. 「漢武帝元鼎二年, 始并百越, 啟七郡於是, 乃置交趾刺史, 以督領 之, 初治廣信」(『水經注』卷 37 ).

11 「建安八年, 張津為刺史, 士奖為交阯太守, 共表立為州, 乃拜津為交州 牧」(『晉書』卷 15 , 交州).

12 「麇泠縣, 漢武帝元鼎六年開都尉治, 交州外域記曰 (中略) 交趾郡及州本治 於此也」(『水經注』卷 37 ). 
the Western Jin (265-420) and cited in Shuijing zhu, holds that in 106 вСЕ, the headquarters of Jiaozhou (the Jiaozhi Department) was moved from Leilou to Guangxin (廣信) in Cangwu (荅梧). ${ }^{13}$ That is, the headquarters of the Jiaozhi Department was in Miling for a very short period before relocating to Leilou, and was relocated again to Guangxin in 106 BCE. However, the headquarters of the Jiaozhi Commandery (and the Jiaozhi taishou) had to remain in the territory of the Jiaozhi Commandery. Where was it, and was it still located in Miling?

Many texts mention that Zhou Chang (周敞) moved the headquarters from Leilou to Longbian in the first half of the second century. However, it is vital to clarify that what was moved was the headquarters of the Jiaozhi Commandery or the Jiaozhi Department. According to Jiu Tangshu (舊唐書) and Taiping huanyu ji (太平環宇記), Zhou Chang was the Jiaozhi taishou, and the relocation from Leilou to Longbian was the relocation of the commandery center (郡守). ${ }^{14}$ Therefore, this event was the relocation of the headquarters of the Jiaozhi Commandery. This evidence shows that by the time of Zhou Chang, the headquarters of the Jiaozhi Commandery was no longer in Miling, but Leilou. This may be confirmed by the remark in Hanshu (漢書) that Leilou was the most important county of the Jiaozhi Commandery. ${ }^{15}$ In addition, Zhou Chang relocated the headquarters of the Jiaozhi Commandery from Leilou to Longbian, and consequently in Hou Hanshu (後漢書) Longbian was listed as the leading county of the Jiaozhi Commandery. ${ }^{16}$

Furthermore, according to Jinshu (晋書), in 141 CE Zhou Chang again proposed that the royal court establish Jiaozhi as a zhou. Although the court did not approve his proposal, it made a concession and promoted Zhou Chang to Jiaozhi cishi, therefore making him head of the department. ${ }^{17}$ This meant that in $141 \mathrm{CE}$, the headquarters of the Jiaozhi Commandery and the Jiaozhi Department were combined in the same location, which was in Longbian. This

13 「王氏交廣春秋曰, 元封五年, 交州自贏㜢縣移治于此」(『水經注』卷37所引 王氏『交廣春秋』).

14 「龍編, 漢交趾郡守治贏㜢, 後漢周敞為交趾太守, 乃移治龍編」(『舊唐書』卷 41 , 安南府).「龍編縣, 東南四十五里十鄉, 漢交趾郡守治嬴僂, 後漢周敞 為交州太守, 乃移治龍編, 言立城之始有蛟龍盤編於江津之間, 因為武城」 (『太平兾宇記』卷 170 , 龍編縣).

15 「交趾郡, (中略) 縣十, 贏㜢, 有差官, 安定, 荷屚, 糜泠, 都尉治, 曲 易, 此帶, 稽徐, 西於, 龍編, 朱蔦」(『漢書』卷28下, 交趾郡).

16 「交趾郡武帝置, 即安陽王國, 雒陽南萬一千里, 十二城, 龍編, 贏淒, 安定, 苟漏, 糜泠, 曲陽, 北帶, 稽徐, 西於, 朱鴶, 封徯 (建武十九年置), 望海 (建武十九年置) 」(『後漢書』志第23, 交趾郡).

17 「順帝永和九年, 交阯太守周敞求立為州, 朝議不許, 即拜敞為交趾刺史」 (『晉書』卷 15 , 交州). 
concurs with what Songshu (宋書) records, namely that in 203 CE, the headquarters of the Jiaozhi Department was located in Longbian. When the Jiaozhi Department was renamed Jiaozhou, the headquarters was moved again from Longbian to Guangxin (Cangwu). ${ }^{18}$ In $211 \mathrm{CE}$, the headquarters of Jiaozhou was moved to Panyu (番禺). In $226 \mathrm{CE}$, Sun Quan (孫權) tried to separate Guangzhou from Jiaozhou, but in the same year, he had to give up the plan because of the rebellion in Jiaozhou. In $262 \mathrm{CE}$, under the reign of Sun Xiu (孫休), Jiaozhou was finally separated from Guangzhou, and the headquarters of Guangzhou was located in Panyu. ${ }^{19}$ Jiaozhou at the time only included counties from Jiaozhi southward, and the headquarters of Jiaozhou was moved back to Longbian. ${ }^{20}$

Based on the texts cited above, Table 1 summarizes the changes in the location of the headquarters of the Jiaozhi Commandery and the Jiaozhi Department.

As seen in Table 1, prior to the tenth century, there is no historical evidence that after the term of Zhou Chang, the headquarters of the Jiaozhi Commandery was relocated back to Leilou. In other words, there is no indication that Shi Xie (137-226) made Leilou his headquarters.

Second, Leilou and Longbian could not have been the same county (縣) (Leilou $\neq$ Longbian). As illustrated in Table 1, in both Hanshu and Hou Hanshu, Leilou and Longbian were listed as two distinct counties. Shuijing zhu (compiled in the early sixth century CE) describes a river that ran through the north of Leilou County, connecting with the King River that originated from the high grounds (高山) of Longbian County. Thus, Shuijing zhu also differentiates Leilou from Longbian, seeing the two as separate units. ${ }^{21}$ Jiu Tangshu and Taiping huanyu ji (both compiled in the tenth century) clearly note the relocation of the headquarters of the Jiaozhi Commandery from Leilou to Longbian.

However, after Vietnam became independent from China in the tenth century, a new opinion emerged in Toàn thu', according to which Leilou was the same as Longbian ("Leilou = Longbian"). In Toàn thu', the chapter on Shi Xie

18 「交趾刺史治龍編, 漢獻帝建安八年, 改曰交州, 治蒼梧廣信縣, 十六年, 徙治南 海番禺縣, 及分為廣州, 治番禺, 交州還治龍編」(『宋書』卷 38 , 交州).

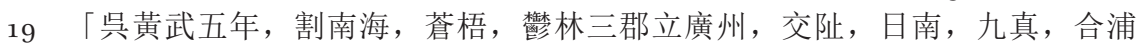
四郡為交州, 戴良為刺史, 值亂不得入, 呂岱擊平之, 復還并交部, 赤烏五 年, 復置珠崖郡, 永安七年, 復以前三郡立廣州」（『晉書』卷 15 , 交州)。 「陳襲臨淮人, 永安七年為交州牧, 值孫諝虐政後, 復分海東四郡為廣州, 以 熊牧為刺史, 海南三郡為交州, 以襲為刺史, 移治龍編」(『安南志略』卷 7 ).

21 其次一水東逕封溪縣南, 又西南逕西于縣南, 又東逕贏㜢縣北, 又東逕北帯 縣南, 又東逕稽徐縣, 涇水注之, 水出龍編縣高山, 東南流入稽徐縣, 注於 中水」(『水經注』卷 37 ). 
TABLE 1 Relocations of the headquarters of the Jiaozhi Commandery and the Jiaozhi Department

\begin{tabular}{|c|c|c|c|}
\hline Year & $\begin{array}{l}\text { Headquarters of the } \\
\text { Jiaozhi Commandery } \\
\text { 交趾郡 } \\
\text { 郡治・郡守 }\end{array}$ & $\begin{array}{l}\text { Headquarters of the } \\
\text { Jiaozhi Department } \\
\text { (Jiaozhou) } \\
\text { 交趾・交州刺史部 } \\
\text { 州治 }\end{array}$ & $\begin{array}{l}\text { Headquarters of } \\
\text { the Guangzhou } \\
\text { Department } \\
\text { (廣州刺史部) } \\
\text { 州治 }\end{array}$ \\
\hline $\begin{array}{l}111 \mathrm{BCE} \\
\text { (元封 } 5 \text { 年) }\end{array}$ & $\begin{array}{l}\text { Miling } \\
\text { 麇泠 }\end{array}$ & $\begin{array}{l}\text { Miling? } \\
\text { 麇泠 }\end{array}$ & \\
\hline $\begin{array}{l}106 \text { BCE } \\
\text { (元鼎6年) }\end{array}$ & $\begin{array}{l}\text { Leilou } \\
\text { 贏㜢 }\end{array}$ & $\begin{array}{l}\text { Miling } \rightarrow \text { Leilou } \rightarrow \\
\text { Guangxin } \\
\text { 麇泠 } \rightarrow \text { 贏㜢 } \rightarrow \text { 廣信 }\end{array}$ & \\
\hline $\begin{array}{l}\text { First half of } \\
\text { the second } \\
\text { century CE } \\
\text { 交趾太守周敞 }\end{array}$ & $\begin{array}{l}\text { Leilou } \rightarrow \text { Longbian } \\
\text { 贏㜢 } \rightarrow \text { 龍編 }\end{array}$ & $\begin{array}{l}\text { Guangxin } \\
\text { 廣信 }\end{array}$ & \\
\hline $\begin{array}{l}141 \mathrm{CE} \\
\text { (永和6年) }\end{array}$ & $\begin{array}{l}\text { Longbian } \\
\text { 龍編 }\end{array}$ & $\begin{array}{l}\text { Guangxin } \rightarrow \text { Longbian } \\
\text { 廣信 } \rightarrow \text { 龍編 }\end{array}$ & \\
\hline $\begin{array}{l}203 \mathrm{CE} \\
\text { (建安8年) } \\
\text { (交趾刺史部 } \rightarrow \\
\text { 交州) }\end{array}$ & $\begin{array}{l}\text { Longbian } \\
\text { 龍編 }\end{array}$ & $\begin{array}{l}\text { Longbian } \rightarrow \text { Guangxin } \\
\text { 龍編 } \rightarrow \text { 廣信 }\end{array}$ & \\
\hline $\begin{array}{l}211 \mathrm{CE} \\
\text { (建安16年) }\end{array}$ & $\begin{array}{l}\text { Longbian } \\
\text { 龍編 }\end{array}$ & $\begin{array}{l}\text { Guangxin } \rightarrow \text { Panyu } \\
\text { 廣信 } \rightarrow \text { 番禺 }\end{array}$ & \\
\hline $\begin{array}{l}226 \mathrm{CE} \\
\text { (黄武 } 5 \text { 年) } \\
\text { 交州 } \rightarrow \text { (交州+ } \\
\text { 廣州) }\end{array}$ & $\begin{array}{l}\text { Longbian } \\
\text { 龍編 }\end{array}$ & $\begin{array}{l}\text { Panyu } \rightarrow \text { Longbian } \\
\text { 番禺 } \rightarrow \text { 龍編 }\end{array}$ & $\begin{array}{l}\text { Panyu } \\
\text { 番禺 }\end{array}$ \\
\hline $\begin{array}{l}226 \text { CE } \\
(\text { 黄武5年) } \\
(\text { 交州十廣 } \\
\text { 州 }) \rightarrow \text { 交州 }\end{array}$ & $\begin{array}{l}\text { Longbian } \\
\text { 龍編 }\end{array}$ & $\begin{array}{l}\text { Longbian } \\
\text { 龍編 }\end{array}$ & \\
\hline $\begin{array}{l}262 \mathrm{CE} \\
\text { (永安7年) } \\
\text { 交州 } \rightarrow \text { (交州+ } \\
\text { 廣州) }\end{array}$ & $\begin{array}{l}\text { Longbian } \\
\text { 龍編 }\end{array}$ & $\begin{array}{l}\text { Longbian } \\
\text { 龍編 }\end{array}$ & $\begin{array}{l}\text { Panyu } \\
\text { 番禺 }\end{array}$ \\
\hline
\end{tabular}


states, "(Shi Xie) was appointed Jiaozhou taishou, received the title of Long Độ Đình hầu (龍度亭侯), and situated his headquarters in Leilou (also known as Longbian)." With the words "Leilou (also known as Longbian)," Toàn thu' established the equation "Leilou = Longbian." As Toàn thu' was the official historical book of the state, the idea of "Leilou = Longbian" was officially and widely accepted from the fifteenth century onward. And in the twentieth century, some scholars, notably Đỗ Văn Ninh, building on Toàn thư, put forth Hypothesis 3: "Leilou = Longbian."22

The view that "Leilou = Longbian," however, was evidently in conflict with the idea that Leilou $\neq$ Longbian, which is well established in earlier sources, including Hanshu, Hou Hanshu, Shuijing zhu, and Jiu Tangshu. Thus, the earliest sources provide no support for Hypothesis 3: "Leilou = Longbian."

\section{Leilou in Historical Records}

Tested against materials written before the tenth century, Hypothesis 3 does not hold water. Leilou and Longbian under the Han were two different citadels. Before considering the relationship between Leilou, Longbian, and the Lũng Khê Citadel, it is necessary to review the locations of Leilou according to pretenth century literature.

\section{Before the Tenth Century: Leilou Located in the West of Hanoi}

Generally speaking, before the tenth century, it was believed that the Leilou Citadel and Leilou County in the Han were located west of Hanoi.

Although Leilou County was established during the Han and existed until the sixth century $\mathrm{CE},{ }^{23}$ the earliest work that mentions the location of the Leilou Citadel is Yuanhe junxian tuzhi, a geographical text compiled in the early ninth century. Yuanhe junxian tuzhi wrote that "the old Leilou Citadel was located $75 \mathrm{li}$ in the west of Songping (宋平) County—formerly a county under the Han, a part of the Jiaozhi Commandery. In the Later Han, the Jiaozhi cish $i$ located the headquarters here, but it was later moved to Longbian." ${ }^{4}$ So Yuanhe junxian tuzhi holds that Leilou was situated approximately $37 \mathrm{~km}$ to the west of the Protectorate Citadel (modern Hanoi) under the Tang Dyansty.

22 Đỗ Văn Ninh, Ancient Towns in Vietnam, 82-84.

23 Nanqi shu 南齊書 (compiled in the sixth century CE) still listed Leilou as one of the eleven counties in the Jiaozhi Commandery.

24 「連㜢 (音蓮笽) 故城, 在縣西七十五里, 本漢縣, 屬交州郡, 有差官, 後漢 交趾史理於此, 後徙龍編」 (『元和郡縣圖志』卷 38 , 安南, 宋平縣). 
Previously, scholars dismissed what was written in Yuanhe junxian tuzhi as unreliable, because it is the only historical record that suggests that Leilou was situated west of Hanoi. ${ }^{25}$ However, several other sources also indicate that Leilou County under the Han was to the west of Hanoi.Jiu Tangshu states that part of Leilou County of the Han overlapped with Jiaozhi County of the Tang after 627 CE. ${ }^{26}$ Shitao zhi (十道志), cited in Xin Tangshu, indicates that to travel from the Protectorate Citadel to Fengzhou (峯州, Phú Thọ), it was necessary to pass Jiaozhi County. ${ }^{27}$ Because Fengzhou was northwest of Hanoi, part of Jiaozhi County had to be situated west of Hanoi. Besides, the rubbing of the Nhật Tảo (日早) Bell, dated to 948 CE and discovered in Đông Ngạc (Từ Liêm district, Hanoi), also suggests that the area west of Hanoi was part of Lower Từ Liêm hamlet, Jiaozhi County (交趾縣下慈廉村) by the tenth century. ${ }^{28}$

The territory of Jiaozhi County under the Tang Dynasty partly overlapped with the area northeast of Hanoi. According to Jiu Tangshu, 1o li $(5 \mathrm{~km})$ to the northeast of the Protectorate Citadel was Fusheng (福生), which belonged to Jiaozhi County. ${ }^{29}$ The same thing was noted in Tongdian (通典) by Du You (杜佑). ${ }^{30}$ Combining these sources, it is clear that Jiaozhi County under the Tang spanned a vast territory that overlapped the area west and northwest of Hanoi, as well as part of the area to the northeast. According toJiu Tangshu and Yuanhe junxian tuzhi, the territory of Jiaozhi County under the Tang included both Leilou and Longbian counties of the Han. ${ }^{31}$

Furthermore, Leilou County under the Han was partly located southwest of Hanoi. According to Yuanhe junxian tuzhi, Nanding (南定) County (established in $791 \mathrm{CE}$ ) was a part of Leilou County of the Han. Geographically, Nanding

25 Sakurai, "A Reconsideration of Lạc điền," 19.

26 「交趾, 漢交趾郡之羸㜢」 (『舊唐書』卷41, 安南都督府). When investigating the case of Jiaozhi County, it is important to note that the location of Jiaozhi County changed many times. The Jiaozhi County that we mention here was the one established in 627 (貞觀1) under the Tang, named on the basis of "the old Jiaozhi citadel under the Han" (which we believe is the Leilou citadel).

27 「安南經交趾太平, 百餘里至峯州」(『新唐書』卷43下, 峯州都督府).

28 「交趾縣下慈廉村」. Claudine Salmon and Phan Văn Các, eds., Épigraphie en chinois $d u$ Viêt Nam, vol. 1, De l'occupation chinoise à la dynastie des Lý (Paris: Presses de l'École française d'Extrême-Orient, 1998), 47.

29 「東北至交趾縣界福生去十里也」(『舊唐書』卷41, 安南都督府).

30 「東北到交趾縣十里」(『通典』卷 184 , 安南都護府).

31 Yuanhe junxian tuzhi assumes that Jiaozhi County under the Tang was a part of Longbian County under the Han. 「交趾縣本漢龍編縣地」 (『元和郡縣圖志』卷 38 ). 
County under the Tang was situated "6o li to the northeast of the Protectorate Citadel," meaning approximately $30 \mathrm{~km}$ southwest of Hanoi today. ${ }^{32}$

Therefore, Leilou County under the Han was partly located to the west and southwest of Hanoi. This concurs with Yuanhe junxian tuzhi, which located the old Leilou Citadel 75 li west of the Protectorate Citadel. In Jiaozhi County under the Tang, according to Jiu Tangshu, there was also "the old Jiaozhi Citadel of the Han." ${ }^{3}$ "The old Jiaozhi Citadel of the Han" mentioned here did not refer to the Longbian Citadel, because as noted earlier, the Longbian citadel was situated in the territory of Longbian County during the Han-Tang period. Therefore, "the old Jiaozhi citadel under the Han," situated in Jiaozhi County under the Tang, could only be the Leilou Citadel.

In short, in pre-tenth century literature, it was widely accepted that Leilou County and the Leilou Citadel under the Han were located west of Hanoi.

\section{After the Tenth Century: Leilou = Lũng Khê}

From the beginning of the eleventh century, however, new sources appeared that suggested that Leilou was located at the position of the Lũng Khê Citadel (Leilou = Lũng Khê). The earliest sources that contain this view are Thiền uyển tập anh (禪苑集英) and Toàn thú.

First, the Pháp Hiền (法賢) chapter in Thiền uyển tập anh referred to Pháp Vân Pagoda as Pháp Vân Pagoda of Leilou (贏㜢法雲寺), implying that the Pháp Vân Pagoda (which overlaps with the area of the Lũng Khê Citadel) was part of Leilou County. ${ }^{34}$ Although the chapter of Thông Biện (通辨) did not directly suggest that "Leilou = Lũng Khê," it mentioned that Khâu Đà La (丘陀羅), Ma La Kỳ Vực (摩羅老域), and Pháp Hiền, the famous Zen masters associated with Pháp Vân Pagoda, once practiced Buddhism in the Leilou area. ${ }^{35}$ Thus the view that "Leilou = Lũng Khê" already appeared in the two chapters of Thiền uyển tập anh.

However, in Thiền uyển tập anh, the chapters on Tỳ Ni Đa Lưu Chi (毘尼多 流支) (Vinītaruci, the master of Pháp Hiền) and Sùng Phạm (崇範) referred to

32 「南定縣 (中下, 東北至府六十里) 本漢贏㜢縣地, 貞元七年于此置南定縣, 其舊南定縣, 在今縣東南二百餘里, 羈縻長州側近, 開元十年後廢」(『元和 郡縣圖志』卷 38 ).

33 「武德四年, 於宋平置宋州, 領宋平, 弘教, 南定三縣, 五年, 又分宋平置交 趾, 懷德二縣, 自貞觀元年, 廢南宋州, 以弘教, 懷德, 交趾三縣省入宋平 縣, 移交趾縣, 名於漢故交趾城置」(『舊唐書』卷 41 , 安南府).

34 「贏㜢法雲寺」(『禪苑集英』法賢傳).

35 「佛法初來江東, 未被而贏㜢又重創興寶刹二十餘所, 度僧五百餘人, 譯経一 十五卷, 以其先之故也, 于時則已有比丘名魔羅耆域, 康僧會, 支僵良, 牟 搏之屬在」(『禪苑集英』通辨傳). 
Pháp Vân Pagoda of Cổ Châu Hamlet of Longbian (龍編古州鄉法雲寺), implying that Pháp Vân Pagoda was situated in the Cổ Châu hamlet of Longbian. ${ }^{36}$ Although the chapter on Thiền Nham (禪岩) mentions the location of another pagoda, Trí Quả (致果), it shares the view that Cổ Châu hamlet was situated in the Longbian area. ${ }^{37}$ Therefore, there are two views that coexist in Thiền uyển tập anh: "Lũng Khê = Leilou" (the chapters on Pháp Hiền and Thông Biện), and "Lũng Khê = Longbian" (the chapters on Tỳ Ni Đa Lưu Chi, Sùng Phạm, and Thiền Nham).

Second, according to Toàn thư, in 1188 CE, Emperor Lý Cao Tông went to Pháp Vân Pagoda of Duềnh Bà ( 瀛婆法雲寺). Duềnh Bà (瀛婆) was believed to be an error for Leilou (贏㜢), so this text has been considered as evidence that "Lũng Khê = Leilou." However, in the same text, the note of Ngô Sĩ Liên, the main editor of Toàn thu', reads: "at the beginning of our dynasty [i.e., the Lê], we still had this custom” (今朝國初猶乃舊俗). Meanwhile, in Đại Việt sủ̉ lược, compiled during the Trần, Pháp Vân Pagoda was never called "Pháp Vân Pagoda of Duềnh Bà (or Leilou)" but "Pháp Vân Pagoda of Cổ Châu” (古州法 雲寺). This implies that the text of Toàn thu' was edited by Ngô Sĩ Liên in the fifteenth century. ${ }^{38}$

Third, in the Shi Xie chapter of Toàn thu', Ngô Sĩ Liên suggests that the Leilou Citadel was situated in Lũng Khê. First, in the account of the life of Shi Xie, Ngô Sĩ Liên states that Shi Xie located his headquarters in Leilou, noting that "(Leilou) means Longbian" ("Leilou = Longbian"). Then, in his comments at the end of the Shi Xie chapter, Ngô Sĩ Liên remarks that the shrine dedicated to Shi Xie (located in the area of Lũng Khê) was once part of "the former Longbian Citadel" ("Lũng Khê = Longbian"). In other words, by combining the two equations "Leilou = Longbian" and "Lũng Khê = Longbian," Ngô Sĩ Liên indirectly suggests that Leilou was Lũng Khê ("Leilou = Lũng Khê").

The question, however, is whether Shi Xie really based his headquarters in Leilou. As demonstrated in the previous section, pre-tenth century literature never mentioned Shi Xie's headquarters in Leilou. So where did this idea come from?

The following table compares the notes in Việt diện u linh, Toàn thu', and Sanguo zhi in order to prove that the idea that "Shi Xie's headquarters = Leilou"

\footnotetext{
36 「龍編古州鄉法雲寺」 (『禪苑集英』比尼多流支傳・崇範傳).

37 「龍編古州智果寺」 (『禪苑集英』禪岩傳). Trần Quốc Vượng, “The Historical and Geographical Book of Hanoi Region (before the eleventh century)," Journal of Historical Studies 15 (1960): 50 .

38 「夏五月旱, 帝親幸瀛婆法雲寺, 祈雨, 因迎法雲佛像歸報天寺, 今朝國初猶 乃舊俗」（『大越史記全書』本紀卷 4 ，戊申天資嘉瑞3年〈1188年〉 5 月條).
} 
in Toàn thu' originated from Việt điện u linh. What was written in Việt điện u linh, however, was largely unsubstantiated. Table 2 cites specific sentences in Việt diện $u$ linh and compares them with parallel statements in Toàn thu' and Sanguozhi.

TABLE 2 ShiXie in Sanguo zhi, Việt điện u linh, and Toàn thư

\begin{tabular}{|c|c|c|c|}
\hline No. & $\begin{array}{l}\text { Sanguo zhi } \\
\text { 三國志 }\end{array}$ & $\begin{array}{l}\text { Việt điện u linh } \\
\text { 粵甸幽靈 }\end{array}$ & $\begin{array}{l}\text { Toàn thư } \\
\text { 大越史記全書 }\end{array}$ \\
\hline 1 & 士啍字威彥，蒼梧廣信人也 & $\begin{array}{l}\text { 王姓士名㘜, } \\
\text { 蒼梧廣信人也 }\end{array}$ & $\begin{array}{l}\text { 姓士諱爕, 字威彥, 蒼梧 } \\
\text { 廣信人也 }\end{array}$ \\
\hline 2 & 其先本魯國汶陽人 & 其先魯國汶陽人 & 其先魯國汶陽人也 \\
\hline 3 & 至王䒭之亂, 避地交州 & $\begin{array}{l}\text { 值王莽亂, 避 } \\
\text { 地於此 }\end{array}$ & $\begin{array}{l}\text { 北朝王莽之亂, 避地於 } \\
\text { 我越 }\end{array}$ \\
\hline 4 & $\begin{array}{l}\text { 六世至䝨, 父賜, 桓帝時, } \\
\text { 為日南太守 }\end{array}$ & $\begin{array}{l}\text { 世至王, 父名 } \\
\text { 賜, 漢桓帝 } \\
\text { 時, 為日南 } \\
\text { 太守 }\end{array}$ & $\begin{array}{l}\text { 六世至王, 父賜, 漢桓帝 } \\
\text { 時, 為日南太守 }\end{array}$ \\
\hline 5 & $\begin{array}{l}\text { 燮少游學京師，事潁川劉 } \\
\text { 子奇 }\end{array}$ & 王少游學漢京 & $\begin{array}{l}\text { 王少遊學漢京, 從穎川劉 } \\
\text { 子奇 }\end{array}$ \\
\hline 6 & 治左氏春秋 & 治左氏春秋 & 治左氏春秋為注解 \\
\hline 7 & $\begin{array}{l}\text { 察孝廉, 補尚書郎, 公事 } \\
\text { 免官 }\end{array}$ & $\begin{array}{l}\text { 挙孝廉, 補尚 } \\
\text { 書郎, 以公事 } \\
\text { 免官 }\end{array}$ & $\begin{array}{l}\text { 舉孝廉, 補尚書郎, 以公 } \\
\text { 事免官 }\end{array}$ \\
\hline 8 & $\begin{array}{l}\text { 父賜喪関後, 舉茂才, 除 } \\
\text { 巫令 }\end{array}$ & $\begin{array}{l}\text { 居父喪関後, } \\
\text { 舉茂才, 除巫 } \\
\text { 陽令 }\end{array}$ & $\begin{array}{l}\text { 父喪関（音鈌, 盡也）後 } \\
\text { 舉茂才, 除巫陽令, }\end{array}$ \\
\hline 9 & 遷交阯太守， & $\begin{array}{l}\text { 獻帝時, 遷交 } \\
\text { 阯太守 }\end{array}$ & 遷交州太守，封龍度亭侯 \\
\hline 10 & 漢遣張津為交州刺史， & 時張津交州刺史 & $\begin{array}{l}\text { 及漢帝遣張津為刺史津 } \\
\text { (守任在漢建安六年) }\end{array}$ \\
\hline 11 & & $\begin{array}{l}\text { 漢末三國交 } \\
\text { 争, 王治贏㜢 } \\
\text { 及廣信二所 }\end{array}$ & $\begin{array}{l}\text { 都贏㜢（㜢一作樓, 即龍 } \\
\text { 編), 後陳朝追封善感嘉應 } \\
\text { 靈武大王 }\end{array}$ \\
\hline 12 & 津後又為其將區景所殺 & $\begin{array}{l}\text { 後張津為賊帥區 } \\
\text { 景所害 }\end{array}$ & 為其將區景所殺 \\
\hline 13 & $\begin{array}{l}\text { 而荊州牧劉表遣零陵賴恭代 } \\
\text { 津, 是時蒼梧太守史璜死, } \\
\text { 表又遣吳巨代之, 與恭俱至 }\end{array}$ & $\begin{array}{l}\text { 荊州牧劉表遣零 } \\
\text { 陵賴恭摂交州 }\end{array}$ & $\begin{array}{l}\text { 而荊州牧劉表遣零陵令賴 } \\
\text { 恭代津 }\end{array}$ \\
\hline
\end{tabular}


No. Sanguo zhi

三國志
Việt điện u linh

粤甸幽靈

\section{Toàn thư}

大越史記全書

\begin{tabular}{|c|c|c|c|}
\hline 14 & 漢聞張津死，賜䛓䨝書曰 & $\begin{array}{l}\text { 獻帝聞之，賜 } \\
\text { 玉䨝書曰 }\end{array}$ & 漢帝聞津死，賜王䨝書曰 \\
\hline 15 & 交州絕域，南帶江海 & $\begin{array}{l}\text { 交州絕域,南帶 } \\
\text { 江海 }\end{array}$ & 交州絕域, 南帶江海 \\
\hline 16 & 上恩不宣，下義隹隔 & $\begin{array}{l}\text { 上恩不宣, 下 } \\
\text { 義雍塞 }\end{array}$ & 上恩不宣, 下益雍塞 \\
\hline 17 & $\begin{array}{l}\text { 知逆賊劉表又遣賴恭闃看 } \\
\text { 南土 }\end{array}$ & $\begin{array}{l}\text { 逆賊劉表又遣賴 } \\
\text { 恭窥看南土 }\end{array}$ & $\begin{array}{l}\text { 如逆賊劉表, 又遣賴恭窺 } \\
\text { 看南土 }\end{array}$ \\
\hline 18 & $\begin{array}{l}\text { 今以燮為綏南中郎將, 董督 } \\
\text { 七郡, 領交阯太守如故 }\end{array}$ & $\begin{array}{l}\text { 今以卿為綏南中 } \\
\text { 郎將，董督七 } \\
\text { 郡，領交阯太 } \\
\text { 守如故 }\end{array}$ & $\begin{array}{l}\text { 今以卿為綏南中郎將, 董 } \\
\text { 督七郡, 領交州太守如故 }\end{array}$ \\
\hline 19 & 後絯遣吏張旻奉貢詣京都 & $\begin{array}{l}\text { 王遣張旻詣隔 } \\
\text { 京, 貢獻方物 }\end{array}$ & $\begin{array}{l}\text { 王遣吏張旻奉貢, 請漢 } \\
\text { 京都 }\end{array}$ \\
\hline 20 & 是時天下坒亂, 道路斷絕 & $\begin{array}{l}\text { 是時天下喪 } \\
\text { 亂, 道路阻絕 }\end{array}$ & 是時天下喪亂, 道路斷絕 \\
\hline 21 & 而焂不廢貢職 & 而王能修職貢 & 而王不廢職貢 \\
\hline 22 & $\begin{array}{l}\text { 特復下詔, 拜安遠將軍, 封 } \\
\text { 龍度亭侯 }\end{array}$ & $\begin{array}{l}\text { 漢帝復下詔, } \\
\text { 拜安遠將軍, } \\
\text { 龍度亭侯 }\end{array}$ & $\begin{array}{l}\text { 漢帝複下詔, 拜安遠將 } \\
\text { 軍, 封龍度亭侯 }\end{array}$ \\
\hline 23 & $\begin{array}{l}\text { 後巨與恭相失, 舉兵逐恭, } \\
\text { 恭走還零陵, }\end{array}$ & $\begin{array}{l}\text { 後蒼梧太守吳巨 } \\
\text { 與賴恭相失, } \\
\text { 舉兵逐之，恭 } \\
\text { 走零陵 }\end{array}$ & $\begin{array}{l}\text { 後蒼梧太守吳巨與恭相 } \\
\text { 失, 舉兵逐之, 恭走還 } \\
\text { 零陵 }\end{array}$ \\
\hline
\end{tabular}

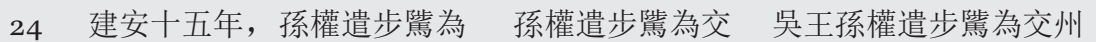 交州刺史 州刺史 刺史

25 騭到, 繂率兄弟奉承節度

騭到, 王率

騭到，王率兄弟奉承節度

兄弟

26 而吳巨懷異心, 騭斬之, 誘導豪姓雍闘 等, 率郡民 權加偹為左將軍, 建安末 附吳

後王遣子剑（魚錦反）入
質于吳王，吳王以為武昌
太守，
王又誘導益州豪姓雍闘
（可亥反）等，率郡民
人，使遙東附吳

27 權益嘉之, 遷衞將軍, 吳益嘉之, 升 封龍編侯 年, 誉遣子应昌太守, 容又誘導益州豪姓雍闘等, 率郡人民使遙東附 吳王益嘉之, 遷衛將軍, 衛將軍, 龍封龍編侯 編侯 
TABLE 2 Shi Xie in Sanguo zhi, Việt điện u linh, and Toàn thư (cont.)

\section{No. Sanguo zhi}

三國志
Việt điện u linh

粵甸幽靈

王遣使詣吳, 貢雜香細葛, 明珠，玳瑁， 翡翠, 犀象及 檳榔，龍眼 之類

吳王賜書，慰 答之

王之弟有三子
細葛,

輯以千數, 明珠, 大貝, 流離, 翡翠, 瑇瑁, 犀, 象之珍, 奇物異果, 蕉, 邪, 龍眼之屬, 無歳不至, 壹時貢馬, 凡數百匹

29 權軴為書, 厚加龍賜, 以答尉之

30
篮乃豊領合浦太守, 次弟 徐聞令, 黃領九真太守, 疅（音于鄙反, 見字林, ) 嫹弟武, 領南海太守
一領合浦太守

（今廉州）， 一領九真太守

（今清化）,

一領南海太守

（今廣州）

\section{Toàn thu'}

大越史記全書

王每遣使詣吳，致雜香細 葛, 輙以千數, 明珠, 大 貝, 琉璃, 翠羽, 瑇瑁, 犀象之珍奇, 及異果, 蕉椰, 龍眼之屬, 無歲不 至, 又貢馬, 凡數百匹 吳王作書, 厚加寵賜, 以 慰答之 王之弟三人

倣性寬厚，謙

器禮寬厚，謙虛下士

虛下士

33 中國士人往依, 避難者以 漢朝名儒多往依 國人愛之, 皆呼士王, 漢 百數

之，以避亂者 之名士避難往依者以百數 數百人, 州人 呼王曰大王

34 陳國袁徽與尚書令荀或書曰 時孔袁徽與尚書 丁亥二十一年，漢建安十 令荷或書曰 二年, 漢袁徽遺尚書令 荷械書曰

35 交阯士府君，既學問優博，交州士府君， 交州士府君，既學問優 又達於從政 學問優博，達 博, 又達於從政 於從政

36 處大亂之中, 保全一郡 大亂之中，保＼cjkstart處大亂之中，保全一郡 全一方

37 二十餘年, 疆埸無事, 民不 二十餘年, 疆 二十餘年, 彊場無事, 民 失業, 羇旅之徒, 皆蒙其慶 埸無事，民不 失業, 羇旅之 不失業, 羈旅之徒, 皆蒙

徒, 皆蒙其賜

王乃表一領合浦太守， 黃領九真太守, 武領南海 太守 其慶 


\begin{tabular}{|c|c|c|c|}
\hline No. & $\begin{array}{l}\text { Sanguo zhi } \\
\text { 三國志 }\end{array}$ & $\begin{array}{l}\text { Việt điện u linh } \\
\text { 粤甸幽靈 }\end{array}$ & $\begin{array}{l}\text { Toàn thư } \\
\text { 大越史記全書 }\end{array}$ \\
\hline 38 & 雖䆬融保河西, 曷以加之 & $\begin{array}{l}\text { 雖竇融保河 } \\
\text { 西, 曷以加之 }\end{array}$ & 雖竇融保河西, 曷以加之 \\
\hline 39 & 狺兄弟並為列郡，雄長一州 & $\begin{array}{l}\text { 王之弟並為郡 } \\
\text { 守, 雄長一州 }\end{array}$ & 兄弟並為列郡, 雄長一州 \\
\hline 40 & 出入鳴鍾磬, 備具威儀 & $\begin{array}{l}\text { 王出入鳴鐘 } \\
\text { 磬, 備儀杖 }\end{array}$ & 出入鳴鐘磬, 備具威儀 \\
\hline 41 & 笳簫鼓吹, 車騎滿道 & $\begin{array}{l}\text { 笳簫鼓吹, 車 } \\
\text { 騎滿道 }\end{array}$ & 笳皷簫吹, 車騎滿道, \\
\hline 42 & $\begin{array}{l}\text { 胡人夾轂焚燒香者, 常有 } \\
\text { 數十 }\end{array}$ & $\begin{array}{l}\text { 州人夾轂焚香迎 } \\
\text { 送, }\end{array}$ & $\begin{array}{l}\text { 胡人夾轂焚香者, 常有 } \\
\text { 數十 }\end{array}$ \\
\hline 43 & $\begin{array}{l}\text { 當時貴重, 震服百蠻, 尉他 } \\
\text { 不足踰也 }\end{array}$ & $\begin{array}{l}\text { 當時貴重, 威 } \\
\text { 服百蠻，尉他 } \\
\text { 不能踰也 }\end{array}$ & $\begin{array}{l}\text { 當時貴重, 震服百蠻, 尉 } \\
\text { 佗不能逾也 }\end{array}$ \\
\hline 44 & $\begin{array}{l}\text { 爕在郡四十餘歲, 黃武五 } \\
\text { 年, 年九十卒 }\end{array}$ & $\begin{array}{l}\text { 王在位四十 } \\
\text { 年, 壽九十年 }\end{array}$ & 在位四十年，壽九十年 \\
\hline
\end{tabular}

As seen in Table 2, except in the case of sentences 11 and 30, Việt điện u linh copied almost every word in the Shi Xie story in Sanguo zhi. In Việt diện u linh, only some characters were modified: for example, Jingshi (京師) in Sanguo zhi in sentence 5 was changed to Hanjing (漢京), and the character cha (察) in sentence 8 was changed to $j u$ (挙). In Việt diện u linh, some content from Sanguo zhi was also removed-for example, the section about Liu Ziqi (劉子奇) in sentence 5 . In the case of sentences 31 onward, the order of the sentence was changed. In Sanguo zhi, these sentences were in the first section, but in Việt diện u linh they were relocated to later sections.

Sentence 30, "wang zhi di you sanzi" (王之弟有三子), was inferred from sentence 31 in Sanguo zhi (Shi Xie had three younger siblings), but Việt điện u linh mistook "the three siblings" as "the three children of his younger brother."

In Sentence 11, Việt điện $u$ linh added a new sentence with no equivalent content in Sanguo zhi一“wang zhi leilou ji guangxin ersuo” (王治贏㜢及廣信 二所)—stating that Shi Xie located the headquarters in the counties of Leilou and Guangxin. Comparing the content of the Shi Xie chapter in Toàn thu with Việt điện u linh and Sanguo zhi in Table 2, it is clear that the idea of "Leilou = Longbian" in Toàn thu' was based on Việt điện u linh. 
In the Shi Xie chapter, although Toàn thu' makes reference to Sanguo zhi, ${ }^{39}$ in general it largely copies Việt diện $u$ linh. This is evidenced by the fact that Toàn thu' retains almost every modification that Việt diện u linh made when copying Sanguo zhi, notably Hanjing in sentence 5, or ju in sentence 8.

Toàn thu also copied from Việt điện u linh, as the comments by Ngô Sĩ Liên in the chapter on Shi Xie show. In the comments, Ngô Sĩ Liên mentioned the event of Linyi warriors unearthing Shi Xie's tomb at the end of the Jin. When compared with the contents of Việt điện u linh (Table 3), it is apparent that Ngô Sĩ Liên copied almost the same contents from Báo cực truyện (報極傳), cited in Việt điện u linh.

When copying from Việt điện u linh, Ngô Sĩ Liên modified sentence 11 (王治贏㜢及廣信二所) in Việt diện u linh into 都贏㜢（㜢一作樓, 即龍編), meaning "situate the headquarters in Leilou, which was Longbian." In short, Toàn thu's idea that "Shi Xie's headquarters = Leilou" was inherited from Việt điện u linh.

\section{"Shi Xie's Headquarters = Leilou" in Việt điện u linh}

The above sections have shown that the idea that "Shi Xie's headquarters = Leilou," a premise that the editors of Toàn thu' including Ngô Sĩ Liên used to establish that "Leilou = Lũng Khê," was actually adopted from Việt diện u linh. The question, then, is how reliable the information in Việt điện u linh is.

As shown above, regarding the life of Shi Xie, in addition to the idea that he established his headquarters in Leilou, Việt điện u linh took most of its details from Sanguo zhi. However, the sentence 王治贏㜢及廣信二所 is in conflict with a historical fact: Shi Xie never situated his headquarters in Guangxin County.

All the historical records concerning Shi Xie in Hou hanshu or Sanguo zhi agree that Shi Xie was not the Jiaozhou cishi (Department Head), but only the Jiaozhi taishou (Commandery Head). Both Hou hanshu and Sanguo zhi indicate that the position of Jiaozhou cishi existed - it was held by Zhang Jin and Bu Zhi, for example. After the Jiaozhou cishi Zhang Jin died, to prevent Shi Xie from taking the side of Liu Biao (劉表), Emperor Xian of the Han—but in practice Cao Cao (曹操) — tried to gain the loyalty of Shi Xie by granting him the authority to “supervise seven commanderies" (董督七郡). The question is whether Shi Xie could possibly have situated the headquarters in Guangxin.

39 That Toàn thu' did make reference to Sanguo zhi is shown by the fact that Toàn thu' added some contents that had been removed from Việt diện u linh, such as the part about 劉子 奇 in sentence 5 , and an erratum that suggests that the phrase 王之弟有三子 in Việt diện u linh, sentence 30 should be 王之弟三人. 
TABLE 3 Comparison of Ngô Sĩ Liên's comments and Việt điện u linh

\begin{tabular}{|c|c|c|}
\hline No & $\begin{array}{l}\text { Việt điện u linh (Báo cực truyện) } \\
\text { 粵甸幽靈（報極傳） }\end{array}$ & $\begin{array}{l}\text { Toàn thư } \\
\text { 大越史記全書 }\end{array}$ \\
\hline 1 & 至晉末, 凡百六十餘年 & 至晉末, 凡百六十餘年 \\
\hline 2 & 林邑入寇, 掘王陵塚 & 林邑人入寇, 掘發王塚 \\
\hline 3 & 見王體不壊 & 見其體面如生 \\
\hline 4 & 大懼, 復埋 & 大懼, 乃復封癗 \\
\hline 5 & 土人以為神, 立廟祀之 & 土人以為神, 立廟事之 \\
\hline 6 & 號曰士王僊 & 號士王僊 \\
\hline
\end{tabular}

First, although Emperor Xian granted Shi Xie the authority to "supervise seven commanderies," Shi Xie was retained as "the Jiaozhi taishou as normal" (領交 阯太守如故). Meanwhile, Liu Biao appointed Lai Gong (賴恭) as the Jiaozhou cishi in place of Zhang Jin, and Wu Ju (吳巨) as the Cangwu taishou in place of Shi Huang (史璜). This meant that even after the death of Zhang Jin, Shi Xie was not the Jiaozhou cishi and his power did not extend to the area of Guangxin (Cangwu).40

In short, all historical records in Houhan shu affirm that Shi Xie was never appointed as a Jiaozhou cishi who ruled over all seven commanderies, and that his highest position was only as a Jiaozhi taishou who ruled over the Jiaozhi Commandery. Guangxin County was part of the Cangwu Commandery, the headquarters of the Jiaozhi (Jiaozhou) cishi. Shi Xie, as the Jiaozhi taishou, could not have established his headquarters in Guangxin. The misleading information in Việt điện u linh might originate from the fact that Shi Xie's homeland was Guangxin, or because the author of Việt điện u linh mistook Shi Xie's position of Jiaozhi taishou for Jiaozhi cishi.

In conclusion, the viewpoint that "Leilou = Lũng Khê" was established very early; passages in the Pháp Hiền and Thông Biện chapters in Thiền uyển

40 「津後又為其將區景所殺, 而荊州牧劉表遣零陵賴恭代津, 是時 蒼梧太守史璜死, 表又遣吳巨代之, 與恭俱至, 漢聞張津死, 賜 䯯䨝書曰, 交州絕域, 南帶江海, 上恩不宣, 下義雍隔, 知逆賊 劉表又遣賴恭闃看南土, 今以䁨為綏南中郎將, 董督七郡, 領交 阯太守如故, 後䃞遣吏張旻奉貢詣京都, 是時天下丧亂, 道路斷 絕, 而赅不廢貢職, 特復下詔拜安遠將軍, 封龍度亭侯」（『三 國志』呉書, 卷49). 
tập anh and in Toàn thu' provided the basis for the conclusion that "Leilou = Longbian = Lũng Khê." However, considering Thiền uyển tập anh as a collection of chapters that were written in different periods, it is clear that that that claim that "Leilou = Lũng Khê" in the Pháp Hiền and Thông Biện chapters was not very popular. Other chapters offered a different opinion, namely, that the area of Lũng Khê was part of Longbian ("Longbian = Lũng Khê").

In Toàn thu', Ngô Sĩ Liên inherited from Việt điện u linh the idea that "Shi Xie's headquarters = Leilou," and he later noted that "Leilou means Longbian (Leilou = Longbian)." So he finally drew on the idea that "the shrine dedicated to Shi Xie was located in the old Longbian Citadel (Lũng Khê)" to establish that "Leilou = Longbian = Lũng Khê." However, Leilou could not be Longbian. Moreover, the idea that "Shi Xie's headquarters = Leilou" in Việt diện u linh was inserted when the author of Việt diện u linh copied Sanguo zhi, and is thus not reliable. Apart from this piece of information, however, Việt diện u linh copied almost every word in Sanguo zhi. It means that Việt diện u linh was not informed by a different and new source of material about Shi Xie. Furthermore, the sentence that linked Shi Xie and Leilou in Việt diện u linh contained misleading information, particularly as it implied that Shi Xie situated his headquarters in Guangxin.

Although the idea that "Leilou = Lũng Khê" developed very early in Vietnam (possibly since the Trần with the compilation of Việt điện u linh), it was not based on reliable material, and it was in conflict with the idea widely held in pre-tenth century literature that Leilou was located west of Hanoi.

Meanwhile, if we assume that "Leilou = Lũng Khê," we will have difficulty locating the Longbian Citadel. If "Leilou = Lũng Khê," because "Leilou * Longbian" there must have been another Longbian Citadel different from Lũng Khê. To solve this puzzle, some scholars have tried to locate Longbian in the provincial center of Bắc Ninh or Yên Phong. However, investigations and fieldwork from French colonial rule until the present day have not found any remains corresponding to the location of this hypothetical Longbian Citadel.

\section{“Longbian = Lũng Khê": Recently Discovered Epigraphic Materials}

Compared to the view that "Leilou = Lũng Khê," the view that "Longbian = Lũng Khê" is even more widely held in the existing literature.

As illustrated above, in Thiền uyển tập anh, apart from the two chapters on Pháp Hiền and Thông Biện, other chapters agree that the Lũng Khê area and adjacent areas belonged to Longbian ("Longbian = Lũng Khê"). Đại Việt sử lược, 
compiled under the Trần, does not contain any information on Leilou in the notes for 1034 and $1161 .{ }^{41}$

Although Toàn thu' embraced the view that "Leilou = Lũng Khê," the manner in which Ngô Sĩ Liên phrased his notes and his comments indirectly implied that in the fifteenth century, the Lũng Khê area was widely known as "the old Longbian Citadel" (龍編故城). First, it is important to clarify how Ngô Sĩ Liên described the area where the shrine dedicated to Shi Xie was situated (Lũng Khê). He did not call the area "the old Leilou Citadel" but rather "the old Longbian Citadel." When he mentioned Leilou, Ngô Sĩ Liên noted that "Leilou means Longbian." This shows that in Ngô Sĩ Liên's view, in the fifteenth century the location of Leilou was not well known. Hence, he had to use Longbian as a cross-reference, for Longbian (the old Longbian citadel) was widely known as the place where the shrine dedicated to Shi Xie was located. ${ }^{42}$ This fact is compatible with Nishimura Masanari's view that "Longbian = Lũng Khê," ${ }^{43}$ which has been confirmed by recently discovered stele inscriptions.

First, in 2004, an inscribed stele from the Jiaozhou Sarira Stupa (Figs. 1, 2), dated $601 \mathrm{CE}$, was discovered along with a stone casket in Trí Quả commune (Thuận Thành, Bắc Ninh). In 601 CE, Emperor Wen of the Sui Dynasty distributed sarira (relics of Buddhist monks) to all thirty zhou across the country, including Jiaozhou. In Jiaozhou a stupa was built to house the sarira, and a stone stele was raised to commemorate the burying of the sarira and the construction of the stupa. The Sarira Stupa inscription matches the notes in Guang hong ming ji (廣弘明集), compiled by Monk Daoxuan (道宣) in the Tang, and this suggests that the place where the stele and the stone casket (presumed to be the original container of the sarira) were discovered was 交州龍編縣禅 衆寺, namely, the Thiền Chúng Pagoda (禅衆寺) in Longbian County.

However, my research on the stele suggests that the location where this stele was discovered in 2004 was not the original location of the Thiền Chúng Pagoda. Rather, based on the notes in Thiền uyển tập anh, the Thiền Chúng

41 「古州法雲寺僧上言, 寺中放光數道, 隨光掘之, 得石函一, 函内有銀函, 銀 函内有金函, 金函内有瑠璃瓶, 瓶中有舍利」（『越史略』卷中, 甲戌天成 7 年〈1034〉條).「秋七月, 起古州法雲寺」 (『越史略』卷中, 辛巳大定 22 年 $\langle 1161\rangle 7$ 月條).

42 There is only one place in Toàn thu', namely in the notes for 1188, where the authors suggested that Pháp Vân Pagoda was located in Leilou. The notes for 1034 and 1161, however, indicate that Pháp Vân Pagoda was located in Cổ Pháp hamlet. We therefore believe that the note "Leilou" in the notes of 1188 was added by Ngô Sĩ Liên himself.

Nishimura, Archaeology and Ancient History of Vietnam, 155-176. 


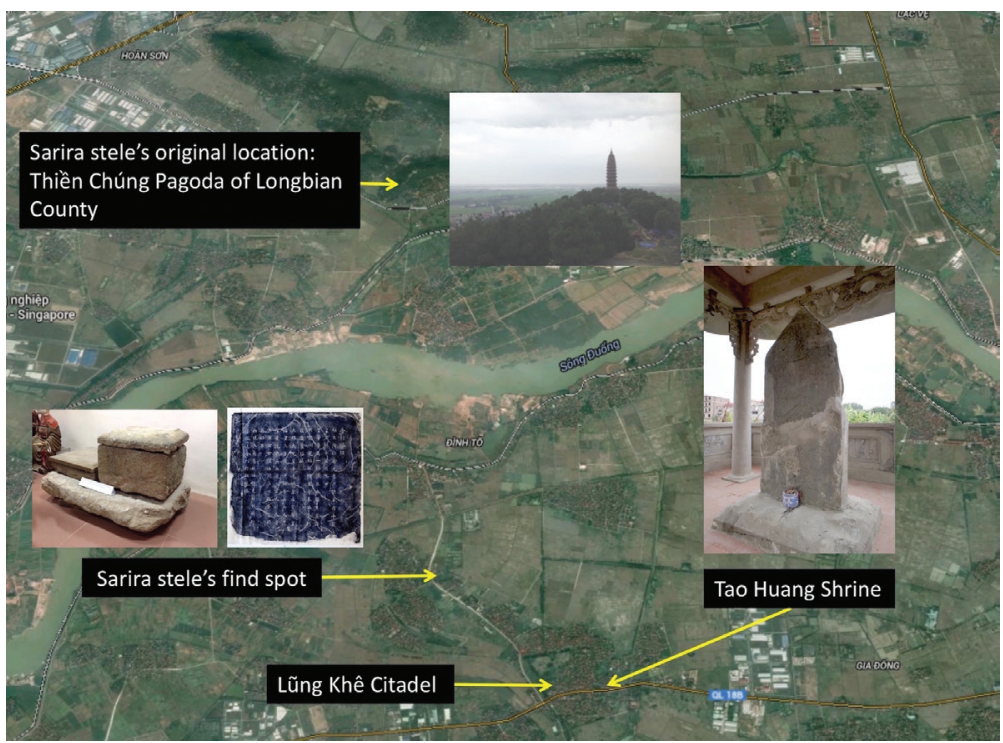

FIGURE 1 Area near the Lũng Khê Citadel, showing the original location of the stele bearing the Sarira Stupa inscription and the place where it was discovered, and the location of the shrine built by Tao Huang. MAP SOURCE: GOOGLE MAPS.

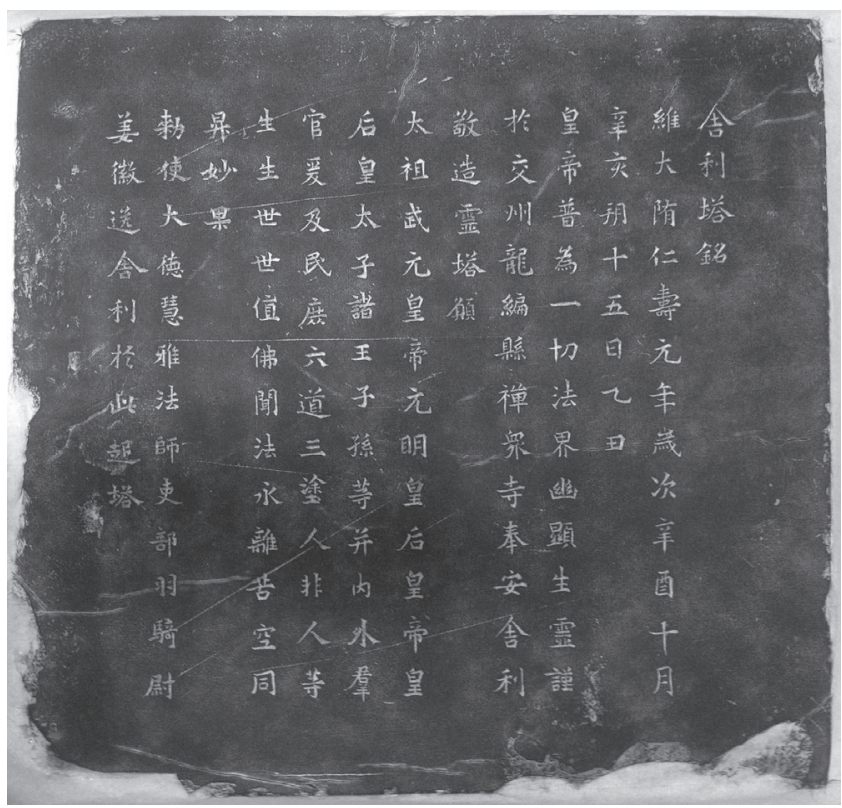

FIGURE 2 Rubbing of the Sarira Stupa inscription discovered at Trí Quả commune (Thuận Thành, Bắc Ninh) in 2012. PHOTO: PHAM LÊ HUY. 
Pagoda in Longbian County under the Sui was located on 天福峯, namely, on Thiên Phúc Mount, one of the eight mounts of Tiên Du Mountain (仙遊山). Tiên Du Mountain was five km north of the area where the stele was discovered in 2004, and approximately $6.5 \mathrm{~km}$ northwest of the Lũng Khê Citadel. ${ }^{44}$

This identification of the original location of the sarira stele suggests that the area of the Lũng Khê Citadel belonged to Longbian County under the Northern and Southern Dynasties-i.e., in the Sui-Tang periods. ${ }^{45}$ Because Longbian County under the Tang was part of Longbian County under the Han, the area of the citadel was also part of Longbian County under the Han.

Regarding the location of the Longbian Citadel under the Han, Yuanhe junxian tuzhi suggests that in Longbian County under the Tang there was a citadel called "the old Jiaozhou Citadel" (交州故城) built by the Jiaozhou cishi, Tao Huang (陶璜), during the Wu period, about $14 l i(7 \mathrm{~km})$ to the east of the Longbian County headquarters. ${ }^{46}$ Although there are still different views on the location of Leilou, the majority of contemporary scholars, including Nishimura, agree that "the old Jiaozhou Citadel" built by Tao Huang was the Lũng Khê Citadel.

This view is further confirmed by a stele inscription discovered in 2013. In the shrine of Tao Huang in Thanh Hoài hamlet (Thuận Thành, Bắc Ninh), near the Lũng Khê Citadel (Fig. 1), Nguyễn Phạm Bằng, a researcher from Bắc Ninh museum, discovered an ancient stone stele. On the front and back of the stele are two inscriptions with different dates. Although the inscription on the front has faded and hence cannot provide much information, the inscription on the reverse has a clear date of $45^{\circ} \mathrm{CE}$. It was composed by a person named Tao Zhenzhi (陶珍之), a descendant of Tao Huang, at Tao Huang's shrine on December 25, 450 CE. Tao Zhen Zhi performed this task at the command of the

44 Phạm Lê Huy, "Nhân Thọ Sarira Stupa and the Recently Discovered Sarira Stupa Inscription in Bắc Ninh” (Nhân Thọ xá lợi tháp và Văn bia tháp xá lợi mới phát hiện tại Bắc Ninh), Vietnam Archaeology (Khảo cổ học) 181 (2013): 60-79; Phạm Lê Huy, “The Recently Discovered Jiaozhou Sarira Stupa Inscription in Vietnam” (新発見の仁寿元年の交州 舎利塔銘について), in Bukkyo Bunmei to Sezoku Chitsuzo (仏教文明と世俗秩序), ed. Shinkawa Tokio 新川登亀男 (Tokyo: Bensei Shuppan, 2014), 28-64.

45 That Tiên Du Mountain was part of Longbian County corresponds to a note in Jiaozhou Diaries (交州記) (cited from Houhan shu) that in the west of Longbian County stood Mount Tiên Sơn, and Taiping huanyu ji wrote that in Longbian County was located Mount Phật Tích佛跡山.「（龍編）縣西帶江, 有仙山數百里」(『後漢書』志第 23 所 引『交州記』), 「佛跡山」(『太平寰宇記』卷 170 , 龍編縣).

46 「交州故城, 在縣東十四里, 点時刺史陶璜所築」(『元和郡縣圖志』卷 38 ). 
Jiaozhou cishi Xiao Jing Xian (蕭景憲), announced by a person named Wang Fa Ling (王法齡) on November 10 of the same year. ${ }^{47}$

The discovery of this stele indicates that Tao Huang's shrine in Thanh Hoài hamlet was built and redecorated no later than the fifth century. Because the shrine was located only $2 \mathrm{~km}$ to the west of the Lũng Khê Citadel, it is important evidence that the Lũng Khê Citadel was the Longbian Citadel built by Tao Huang. ${ }^{48}$

\section{Conclusion}

In Vietnam, it has long been held that Leilou and Longbian were the same citadel ("Leilou = Longbian"). However, building on ideas proposed by Trần Quốc Vượng and Nishimura Masanari, ${ }^{49}$ this paper has examined historical documents and reached the conclusion that in pre-tenth century records, Leilou and Longbian were listed as two distinct administrative counties ("Leilou $\neq$ Longbian"). Early records such as Hanshu, Hou Hanshu, and Shuijing shu provide good evidence for rejecting the view that Leilou and Longbian were the same citadel.

Regarding the location of the Leilou Citadel under the Han, some materials in post-tenth century literature state that the Leilou Citadel and Leilou County under the Han were located west of modern Hanoi. However, as Vietnam entered the era of independence, a new idea emerged that Leilou was located in the area of the Lũng Khê Citadel and surrounding areas, notably in Toàn thu and the chapters on Pháp Hiền and Thông Biện in Thiền uyển tập anh.

In the fifteenth century, Ngô Sĩ Liên and Toàn thu' played an important role in disseminating the idea that Leilou was located in Lũng Khê. The equation of Leilou with Lũng Khê in Toàn thu' was largely based on the statement in Việt diện u linh that "Shi Xie situated his headquarters in Leilou and Guangxin." However, this statement cannot be trusted. Throughout his lifetime, Shi Xie's

47 Phạm Lê Huy, "Research on the stele of Đào Hoàng shrine (Thanh Hoài commune, Thuận Thành district, Bắc Ninh province)” (Khảo cứu Bia Miếu Đào Hoàng [Nghè thôn Thanh Hoài, Thuận Thành, Bắc Ninh]), Vietnam Archaeology (Khảo cổ học) 199 (2016): 48-59.

48 The assumption that Tao Huang's citadel was the Longbian Citadel also agrees with the notes of Jinshu. According to the Wang Liang 王諒 chapter in Jinshu, in the fourth century CE, when Wang Liang fought Liang Shuo 梁碩 for the post of Jiaozhou Department head, they fought battles in Longbian. 「諒陰謀誅碩, 使客刺之, 弗克, 遂率眾圍 諒於龍編」(『晉書』卷89, 王諒傳).

49 Trần Quốc Vượng, "The Positon of Luy Lâu," 3-7; Nishimura, Archaeology and Ancient History of Vietnam, $155^{-176 .}$ 
highest position was the head of Jiaozhi Commandery, not the head of Jiaozhi Department (Jiaozhou). Shi Xie therefore could not have situated his headquarters in the Guangxin Commandery as written in Việt diện u linh. The confusion in Việt điện u linh (and later Toàn thu') may have originated because Shi Xie's homeland was Guangxin, or because the author of Việt diện u linh failed to recognize the difference between the positions of the Jiaozhi taishou and the Jiaozhou cishi.

When Ngô Sĩ Liên compiled the Shi Xie chapter of Toàn thu', he cited the statement in Việt diện $u$ linh as evidence that Shi Xie had situated his headquarters in Leilou. Because Shi Xie's shrine was located in the area of the Lũng Khê Citadel, Ngô Sĩ Liên concluded that Leilou was Lũng Khê. And a new body of literature in the later period-Toàn thu', stone stele inscriptions (the earliest being the stele 贏㜢城重興聖廟碑, $1661 \mathrm{CE}$ ), the records in Việt sử thông giám cương muc, and Đại Nam nhất thống chí-adopted the idea that "Leilou = Longbian = Lũng Khê," leading to the conclusion that "Lũng Khê = Leilou."

By examining the texts in Thiền uyển tập anh and Toàn thu', it can be shown that apart from the idea that "Leilou = Lũng Khê," there is another, more widely held idea that "Longbian = Lũng Khê." In Thiền uyển tập anh, the view that "Leilou = Lũng Khê" existed only in the Pháp Hiền and Thông Biện chapters, ${ }^{50}$ while other chapters such as Tỳ Ni Đa Lưu Chi, Sùng Phạm, and Thiền Nham all agree that the area of Lũng Khê and the surrounding areas were the same as Longbian. Although Ngô Sĩ Liên adopted the view that "Leilou = Lũng Khê," he phrased his notes in Toàn thu' in a manner that demonstrates that by the fifteenth century, the area of Shi Xie's shrine (Lũng Khê Citadel) was widely known as "the old Longbian Citadel," not Leilou. Toàn thu' noted that Leilou "means Longbian," further supporting the above view.

Given the existing evidence, the view that the Lũng Khê citadel was the Longbian Citadel ("Lũng Khê = Longbian"), represented by Nishimura Masanari, is the most plausible opinion and is consistent with what is written in both pre-tenth century texts and recently discovered stele inscriptions. The Sarira Stupa stele inscription of 601 CE clearly shows that the area of Tiên Du Mountain and the surrounding regions (including the Lũng Khê) belonged to Longbian County during the Han, Northern and Southern Dynasties, Sui, and

5o $\quad$ According to Nguyễn Lang (1973), Thông Biện (?-1134), a Zen master of the Ly, was the first to compile the chapters of Tỳ Ni Đa Lưu Chi and his disciple, Pháp Hiền. However, differences in opinion between these chapters regarding the location of Pháp Vân Pagoda show that they were modified at a later stage. For example, in the chapter on Pháp Hiền, there is a note stating, "refer to the chapter on Thông Biện" (詳在通辨禪師傳), which shows that the chapter on Pháp Hiền was edited by someone who lived after Thông Biện. 
Tang periods. During the Wu period, the Longbian Citadel was redecorated by Tao Huang, the Jiaozhou cishi. Although not of decisive importance, the inscription dated to $450 \mathrm{CE}$ discovered to the east of Lũng Khê in 2013 supports this view. Archaeological findings show that the Longbian - Lũng Khê Citadel was used until the Northern and Southern Northern Dynasties and the Sui. Under the Tang, the Longbian - Lũng Khê Citadel was no longer used as the headquarters of Longbian County, the latter being 14 li east of the Lũng Khê Citadel.

If we accept the hypothesis of Nishimura Masanari that the Lũng Khê Citadel was the Longbian Citadel, the question then is how to pinpoint the location of the Leilou Citadel under the Han. If Yuanhe junxian tuzhi's assertion that the Leilou Citadel under the Han was located 75 li to the west of the capital of the Protectorate under the Tang is correct, it can be hypothesized that the Quèn Citadel in the area of Tuyết Nghĩa commune (Quốc Oai, Hà Nội) had some connection with the Leilou Citadel under the Han. Indeed, fieldwork on the Quèn Citadel has shown that it was constructed during the Han period. ${ }^{51}$

51 Đỗ Văn Ninh, "Quèn Citadel - The Base of Đỗ Cảnh Thạc, One of the Twelve Warlords in the Tenth Century” (Thành Quèn, căn cứ của Đỗ Cảnh Thạc, một trong mười hai sứ quân thế kỷ thứ X), Journal of Historical Studies (Nghiên cứu Lịch sử) 132 (1970): 93-94; Nishimura, Archaeology and Ancient History of Vietnam, 167. 